\title{
Structural and morphological characterizations of pure and Ce-doped ZnO nanorods hydrothermally synthesized with different caustic bases
}

\author{
Ait Abdelouhab ${ }^{1}$ Z., Djouadi ${ }^{1, *}$, D., Chelouche $^{1}$ A., Hammiche $^{1}$ L., Touam $^{2}$ T. \\ ${ }^{1}$ Laboratoire de Génie de 1'Environnement (LGE), Université de Bejaia, 06000, Bejaia, Algérie \\ ${ }^{2}$ Laboratoire des Semi-conducteurs, Université Badji Mokhtar, BP 12 Annaba 23000, Algérie
}

\begin{abstract}
This investigation concerns the synthesis as well as structural and morphological characterizations of pure and Ce-doped $\mathrm{ZnO}$ nanorods. The samples were synthesized by simple low-temperature hydrothermal process using respectively $\mathrm{NaOH}$ and $\mathrm{KOH}$ as caustic bases. The as-synthesized nanorods were characterized in terms of their morphological, structural, compositional and vibrational properties. The sizes of the rods were found to be $1.5 \mu \mathrm{m}$ to $2 \mu \mathrm{m}$ in length and $250 \mathrm{~nm}$ to $300 \mathrm{~nm}$ in diameter. The presence of $\mathrm{Ce}$ ions in $\mathrm{ZnO}(\mathrm{NaOH})$ favored the agglomeration of the rods to form flower-like nanostructures. EDAX measurements showed $\mathrm{Zn}$ rich materials with high oxygen vacancy concentration. XRD results indicated that the synthesized $\mathrm{ZnO}$ nanorods possess a pure wurtzite structure with good crystallinity. It has also been found that Ce doping deteriorates the crystalline quality of $\mathrm{ZnO}(\mathrm{NaOH})$ and improves that of $\mathrm{ZnO}(\mathrm{KOH})$. The insignificant intensities observed in FT-IR signals confirm that the synthesized nanorods are of high purity. The Raman spectroscopy studies showed that Ce ions shift the vibrational modes towards lower frequencies. The peaks related to $\mathrm{E}_{2}$ (high) mode in $\mathrm{ZnO}(\mathrm{KOH})$ are relatively intense compared to those of $\mathrm{ZnO}(\mathrm{NaOH})$. The peaks are found to be shifted and asymmetrically broadened due to anharmonic effects originating from quantum-phonon-effect confinement.
\end{abstract}

Keywords: ZnO nanorods; hydrothermal synthesis; caustic base; cerium doping; structure; morphology

\section{Introduction}

As an important low-cost basic II-VI semiconductor material, zinc oxide $(\mathrm{ZnO})$ nanostructures have attracted a great deal of interest for their unique characteristics such as n-type native conduction, wide and direct band gap energy $(3.3 \mathrm{eV})$ at room temperature, large exciton binding energy $(60 \mathrm{meV})$, excellent thermal stability, high electron mobility and specific electrical and optical properties [1]. $\mathrm{ZnO}$ can be used for several technological applications in electronics, optoelectronics, gas sensors, photonic devices and photocatalyst [26]. $\mathrm{ZnO}$ nanostructures have been synthesized by various methods. Some of them require complex processes and sophistical equipment, such as magnetron sputter deposition (MSD), chemical vapor deposition (CVD) and pulsed laser deposition

*E-mail: djameldjouadi@yahoo.fr
(PLD) [7-9]. Others, which are based on chemical approaches, such as ultrasonic spray pyrolysis (USP), sol-gel, wet chemical etching (WCE) and hydrothermal methods [10-17], can be operated at low temperature and pressure, are economical, simple in synthesis and provide high quality products. A variety of morphologies including prismatic forms, nanorods, nanotorus, nanoflowers, nanowires, dumbbell-like, whiskers and spheres have been synthesized [3, 5, 7, 9, 13-18]. Due to their large surface area, $\mathrm{ZnO}$ nanorods have been the most frequently synthesized nanostructures. Doping is considered as an effective way to improve $\mathrm{ZnO}$ properties for various applications. Cerium is one of the rare earth metal elements that has a strong effect on structural characteristics of $\mathrm{ZnO}$ nanostructures [6, 13, 16-19]. Ce-doped $\mathrm{ZnO}$ nanorods have been synthesized by various methods: wet-chemical method [10], hydrothermal route [14, 16], CVD [7] and electrochemical 
process [18]. Hydrothermal method is preferred due to its better homogeneity, less energy consumption, inexpensive equipment, environment friendless (no solvents) and the possibility of incorporating extrinsic atoms into the metal oxides.

In this paper, we report the hydrothermal route synthesis of pure and $\mathrm{Ce}$-doped $\mathrm{ZnO}$ nanorods using two different caustic bases $(\mathrm{KOH}$ and $\mathrm{NaOH})$. The main objective is to study the influence of solutes on structural and morphological properties of pure $\mathrm{ZnO}$ nanorods and $\mathrm{ZnO}$ nanorods doped with rare earth element ions. The effect of $\mathrm{Ce}$ ions on the structural characteristics of $\mathrm{ZnO}$ nanorods elaborated in different basic media is also investigated.

\section{Experimental}

\subsection{Preparation methods and conditions}

Undoped $\mathrm{ZnO}$ powders were prepared by hydrothermal approach using zinc acetate dihydrate $\left(\left(\mathrm{Zn}\left(\mathrm{CH}_{3} \mathrm{COO}\right)_{2} \cdot 2 \mathrm{H}_{2} \mathrm{O}\right), 99 \%\right.$, Aldrich $)$ as $\mathrm{Zn}^{2+}$ ions source, distilled water as a solvent, sodium hydroxide $(\mathrm{NaOH})$ and potassium hydroxide $(\mathrm{KOH})$ as caustic bases. In this procedure, two aqueous solutions of zinc acetate dihydrate $(0.2 \mathrm{M})$ and sodium hydroxide $(3 \mathrm{M})$ were mixed and stirred at ambient temperature until the appearance of a whitish precipitate in the solution. Then, the solution was heated up to $95{ }^{\circ} \mathrm{C}$ in a water bath for $1 \mathrm{~h}$. The final alkaline solution, having $\mathrm{pH}$ equal to 12.82 , was filtered and the precipitate was recovered. The recovered precipitate was repeatedly washed with distilled water and dried in ambient air for a few hours. $\mathrm{ZnO}$ powder was formed according to the following chemical reactions:

$$
\begin{aligned}
& \mathrm{Zn}\left(\mathrm{CH}_{3} \mathrm{OO}\right)_{2}+\mathrm{NaOH} \rightarrow \\
& \mathrm{Zn}\left(\mathrm{CH}_{3} \mathrm{COO}\right)(\mathrm{OH})+\mathrm{Na}\left(\mathrm{CH}_{3} \mathrm{COO}\right) \\
& \mathrm{Zn}\left(\mathrm{CH}_{3} \mathrm{COO}\right)(\mathrm{OH})+\mathrm{NaOH} \rightarrow \\
& \mathrm{Zn}(\mathrm{OH})_{2}+\mathrm{Na}\left(\mathrm{CH}_{3} \mathrm{COO}\right) \\
& \mathrm{Zn}(\mathrm{OH})_{2} \rightarrow \mathrm{ZnO}+\mathrm{H}_{2} \mathrm{O}
\end{aligned}
$$

The sodium salt $\mathrm{Na}\left(\mathrm{CH}_{3} \mathrm{COO}\right)$ was removed by the water washing. Finally, the product was heat treated in a furnace in air at $600{ }^{\circ} \mathrm{C}$ for $2 \mathrm{~h}$ to obtain $\mathrm{ZnO}$ powder. In a similar process $\mathrm{ZnO}$ powder was elaborated using the caustic base $\mathrm{KOH}$ instead of $\mathrm{NaOH}$ with the same molarity ( $3 \mathrm{M})$. In this case, the $\mathrm{pH}$ of the mixed solution was 13.26. Ce-doped $\mathrm{ZnO}$ powders were obtained in a similar manner as that described above by adding to the precursor solution an amount of cerium nitrate $\left[\left(\mathrm{CeNO}_{3}, 6 \mathrm{H}_{2} \mathrm{O}\right)\right.$, Aldrich] corresponding to atomic ratio $[\mathrm{Ce}] /[\mathrm{Zn}]=0.01(1 \%)$. All the powders were prepared in an identical way and under the same conditions.

\subsection{Characterization techniques}

All synthesized powders were characterized at ambient temperature. The crystalline structure of the samples was investigated by X-ray diffraction (XRD) with a PanAlytical diffractometer, operating at $40 \mathrm{kV}$ and $30 \mathrm{~mA}$ using $\mathrm{CuK} \alpha$ radiation (wavelength $\lambda=1.54 \AA$ ). Infrared spectra (FT-IR) were recorded with a Shimadzu IRAffinity-1 spectrometer. Scanning electron microscope (SEM) images were obtained by a Quanta 2000 microscope with energy dispersive X-ray (EDAX) spectroscope. EDAX was used to identify the chemical composition of the products. The structural composition of pure and Ce-doped $\mathrm{ZnO}$ powders was studied using Horiba Jobin Yvon HR 800UV $\mu$ Raman spectrometer.

\section{Results and discussion}

Fig. 1 and Fig. 2 show the low-magnification SEM images of pure and Ce-doped $\mathrm{ZnO}$ powders synthesized with $\mathrm{NaOH}$ and $\mathrm{KOH}$, respectively. As can be seen from the micrographs, the synthesized powders have nanorod morphology. In undoped $\mathrm{ZnO}$ samples, the growth of nanorods is characterized with high density and a random distribution. In Ce-doped $\mathrm{ZnO}$ powders synthesized with $\mathrm{NaOH}$ (Fig. 1), the nanorods are gathered to form a flower-like nanostructures. It is shown that the distribution of these flowers-like structures is uniform. Moreover, the $\mathrm{ZnO}$ nanorods are randomly grown and they originate from the center of the flower. It seems that the central part of the flowershaped structures provides a root for the growth 
of these $\mathrm{ZnO}$ nanorods. In Ce-doped $\mathrm{ZnO}$ powder, prepared with $\mathrm{KOH}$, the rods are still randomly distributed and no remarkable agglomeration has been observed. EDAX analysis was done to assess the elemental composition of the synthesized pure and Ce-doped nanorods; the results are mentioned in Fig. 1 and Fig. 2. EDAX spectra show numerous well-defined peaks related only to $\mathrm{Zn}, \mathrm{O}$ and $\mathrm{Ce}$ atoms. This result indicates that the presently prepared nanorods are solely formed of $\mathrm{Zn}, \mathrm{O}$ and $\mathrm{Ce}$ and no peaks related to other impurities have been detected in the EDAX spectra. Thus, these indications confirm that the synthesized nanorods are $\mathrm{Ce}$-doped $\mathrm{ZnO}$. From the compositional values, it can be noted that the rods are $\mathrm{Zn}$ rich. According to published data $[20,21]$, oxygen vacancies $\left(\mathrm{V}_{O}\right)$ should predominate in $\mathrm{Zn}$-rich crystals, since their formation energy is lower than that of zinc interstitials (Zni). It is also observed that the total oxygen contribution drops from 29.84 at.\% (undoped $\mathrm{ZnO}$ ) to 15.99 at.\% ( $\mathrm{ZnO}(\mathrm{NaOH}): \mathrm{Ce})$ and 22.96 at.\% $(\mathrm{ZnO}(\mathrm{KOH}): \mathrm{Ce})$. This result could be due to the creation of $\mathrm{Ce}-\mathrm{O}$ clusters which is more favorable in $\mathrm{NaOH}$ medium. These clusters may play an important role in the agglomeration of $\mathrm{ZnO}(\mathrm{NaOH})$ : $\mathrm{Ce}$ nanorods as described above. The calculated atomic ratio $[\mathrm{Ce}] /[\mathrm{Zn}]$ was found to be $3.7 \%$ in Ce-doped $\mathrm{ZnO}$ synthesized with $\mathrm{NaOH}$ and $1.17 \%$ in the nanorods prepared with $\mathrm{KOH}$. This result indicates that cerium ions are more homogeneously distributed in $\mathrm{KOH}$ solution than in that of $\mathrm{NaOH}$. As shown in the inset in Fig. 2, the enlarged SEM image shows that a typical length of the nanorods is in the range of $1.5 \mu \mathrm{m}$ to $2 \mu \mathrm{m}$, while the diameters are in the range of $250 \mathrm{~nm}$ to $300 \mathrm{~nm}$. The diameters of most of the synthesized rods are almost the same throughout their length with a slight reduction in the diameters at their tips. The inset also shows that the nanorods surfaces are very clean without any particle impurities. The droplets observed at the ends of the nanorods indicate that the obtained nanorods have grown following VSL mechanism [22, 23].

Fig. 3 shows XRD patterns of pure and Cedoped $\mathrm{ZnO}$ nanorods synthesized by hydrothermal route using $\mathrm{NaOH}$ and $\mathrm{KOH}$. All observed peaks between $30^{\circ}$ and $72^{\circ}\left(\left(\begin{array}{lll}1 & 0 & 0\end{array}\right),\left(\begin{array}{lll}0 & 0 & 2\end{array}\right),\left(\begin{array}{lll}1 & 0 & 1\end{array}\right)\right.$,

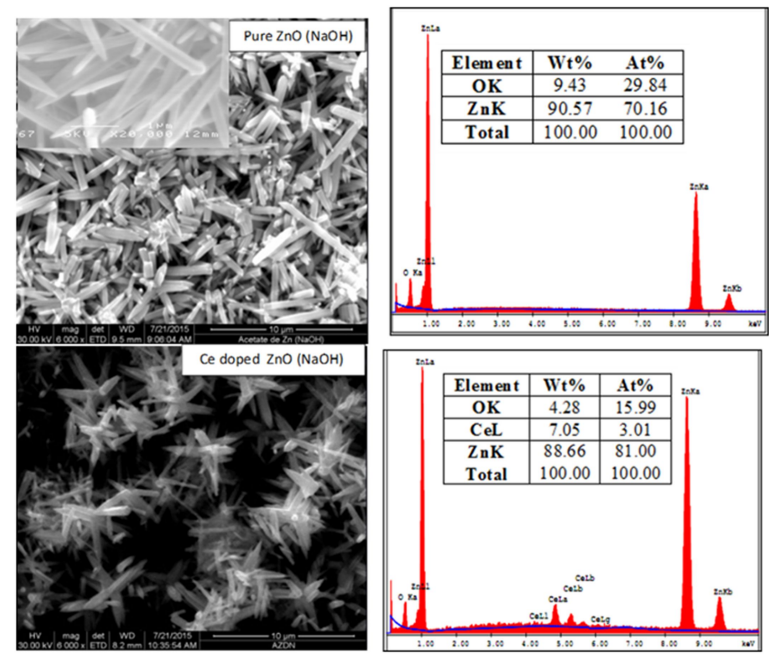

Fig. 1. SEM micrographs and EDAX spectra of undoped and $\mathrm{Ce}$-doped $\mathrm{ZnO}$ nanorods synthesized with $\mathrm{NaOH}$.

(1 0 ( 2) $),\left(\begin{array}{lll}1 & 1 & 0\end{array}\right),\left(\begin{array}{lll}1 & 0 & 3\end{array}\right),\left(\begin{array}{lll}1 & 1 & 2\end{array}\right),\left(\begin{array}{lll}2 & 0 & 0\end{array}\right),\left(\begin{array}{lll}1 & 1 & 2\end{array}\right)$ and $\left.\left(\begin{array}{lll}2 & 1 & 0\end{array}\right)\right)$ are those of the hexagonal wurtzite structure of $\mathrm{ZnO}$ (JCPDS Card No. 79-2205, a = $3.250 \AA$ and $\mathrm{c}=5.207 \AA$ ). The intense XRD peaks indicate that the $\mathrm{ZnO}$ nanorods are polycrystalline with a high degree of crystallinity. No peaks related to cerium or cerium based compounds crystalline forms are detected in XRD patterns. This indicates that the powders are pure and exhibit a single-crystal structure and confirms that the $\mathrm{Ce}$ ions uniformly substitute $\mathrm{Zn}$ sites in the $\mathrm{ZnO}$ lattice. The high peaks intensity, observed in pure $\mathrm{ZnO}(\mathrm{NaOH})$ spectrum compared to that of $\mathrm{ZnO}$ $(\mathrm{KOH})$, are due to the $\mathrm{pH}$ and the high solubility of $\mathrm{KOH}$ in water compared to $\mathrm{NaOH}$. Danishvar et al. [24] reported that dissolution of $\mathrm{ZnO}$ occurs in the presence of high $\mathrm{OH}^{-}$concentration (high $\mathrm{pH}$ ). The effect of $\mathrm{pH}$ on $\mathrm{ZnO}$ properties was widely investigated $[10,25,26]$; it was reported that the XRD peaks intensity increases with the increase of $\mathrm{pH}$ values from $\mathrm{pH} 9$ to $\mathrm{pH} 14$. The most crystallized structure of $\mathrm{ZnO}$ powder was obtained at $\mathrm{pH}$ 9 and the morphology of the products strongly depended on $\mathrm{pH}$ value [26].

The most pronounced XRD peaks $\left(\begin{array}{lll}1 & 0 & 0\end{array}\right)$, (lll $\left.\begin{array}{lll}0 & 2\end{array}\right)$ and $\left.\left(\begin{array}{lll}1 & 0 & 1\end{array}\right)\right)$ shown in Fig. 4, put into evidence the incorporation of cerium ions into zinc ions sites or interstitial sites in $\mathrm{ZnO}$ lattice. As can 


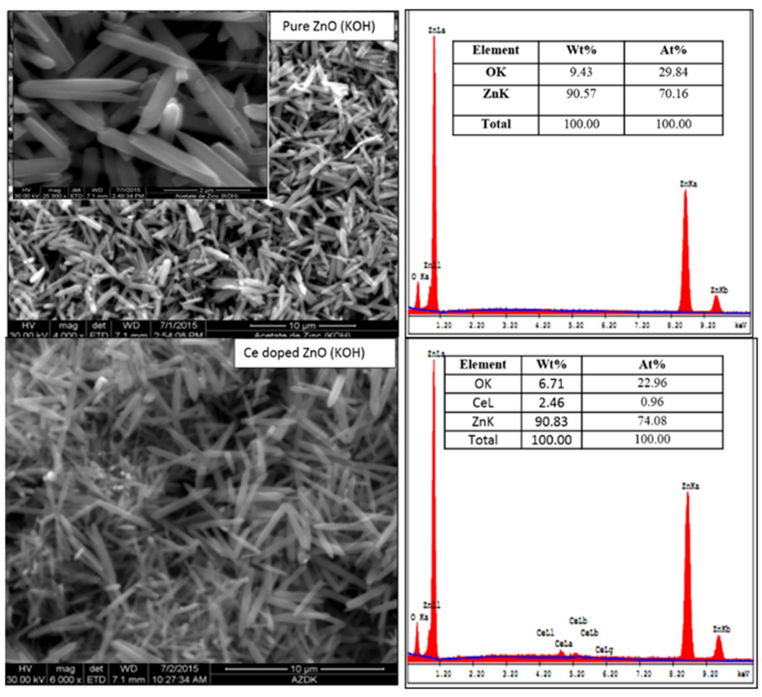

Fig. 2. SEM micrographs and EDAX spectra of undoped and Ce-doped $\mathrm{ZnO}$ nanorods synthesized with $\mathrm{KOH}$.

be seen, the position of Ce-doped $\mathrm{ZnO}$ peaks is shifted toward lower angles compared to those of undoped ones, indicating an increase in the cell parameters after the introduction of $\mathrm{Ce}$ ions into $\mathrm{ZnO}$ lattice. The dopant does not alter the crystal structure but only introduces a slight variation in the lattice parameters, which is also reflected by the shift in the peak position. This shift is due to $\mathrm{Zn}^{2+}$ ions substitution by $\mathrm{Ce}^{3+}$ ions. The difference in ionic radii of $\mathrm{Ce}^{3+}(0.114 \mathrm{~nm})$ and $\mathrm{Zn}^{2+}(0.074 \mathrm{~nm})$ leads to variation in the lattice parameters. The cell parameters: $\mathrm{a}=\mathrm{b}=1 /(\sqrt{ } 3 \sin \theta)$ and $\mathrm{c}=1 / \sin \theta$ of pure and Ce-doped $\mathrm{ZnO}$ were calculated from the positions of the $\left(\begin{array}{lll}1 & 0 & 0\end{array}\right)$ and $\left(\begin{array}{lll}0 & 0 & 2\end{array}\right)$ peaks, respectively. The volume of the $\mathrm{ZnO}$ hexagonal cell $\mathrm{V}$ and the $\mathrm{Zn}-\mathrm{O}$ or $\mathrm{Ce}-\mathrm{O}$ bond length $\mathrm{L}$ were calculated using reported formulas [19]. The degree of crystallinity Xc is given by [27]:

$$
X_{C}=\left(\frac{0.24}{\beta_{002}}\right)^{3}
$$

where $\beta_{00}$ is the full width at half maximum (in degrees) of (l $\left.\begin{array}{lll}0 & 0 & 2\end{array}\right)$ Miller plane. The cell parameters a and c, c/a ratio, cell volume $\mathrm{V}, \mathrm{Zn}-\mathrm{O}$ bond length $(\mathrm{L})$ and $\mathrm{X}_{\mathrm{C}}$, calculated for all samples, are shown in Table 1. Based on Table 1 data, we note that the cell parameters of pure $\mathrm{ZnO}$ synthesized with $\mathrm{KOH}$ are lower than those of a standard $\mathrm{ZnO}$ powder (JCPDS Card No. 79-2205), while those of pure $\mathrm{ZnO}$ synthesized with $\mathrm{NaOH}$ are found to be higher. The introduction of cerium atoms into $\mathrm{ZnO}$ leads to an increase in the lattice parameters, the cell volume and the $\mathrm{Zn}-\mathrm{O}$ length. The degree of crystallinity in pure $\mathrm{ZnO}(\mathrm{NaOH})$ is higher than that of pure $\mathrm{ZnO}(\mathrm{KOH})$. After the introduction of cerium ions into $\mathrm{ZnO}$ lattice, the crystalline quality of $\mathrm{ZnO}(\mathrm{NaOH})$ deteriorates and that of $\mathrm{ZnO}$ $(\mathrm{KOH})$ improves (Table 1 and the inset of Fig. 4). This result indicates that Ce ions occupy only $\mathrm{Zn}$ ions sites in $\mathrm{ZnO}(\mathrm{KOH})$, but $\mathrm{Zn}$ ions sites and interstitials sites in $\mathrm{ZnO}(\mathrm{NaOH})$ due to the high concentration of cerium ions observed in $\mathrm{ZnO}$ synthesized with $\mathrm{NaOH}$ (EDAX results). The X-ray diffraction analysis of these powders gives the ratio of crystal lattice parameters $\mathrm{c} / \mathrm{a} \cong 1.60$, which is also characteristic of the $\mathrm{ZnO}$ hexagonal crystal lattice.

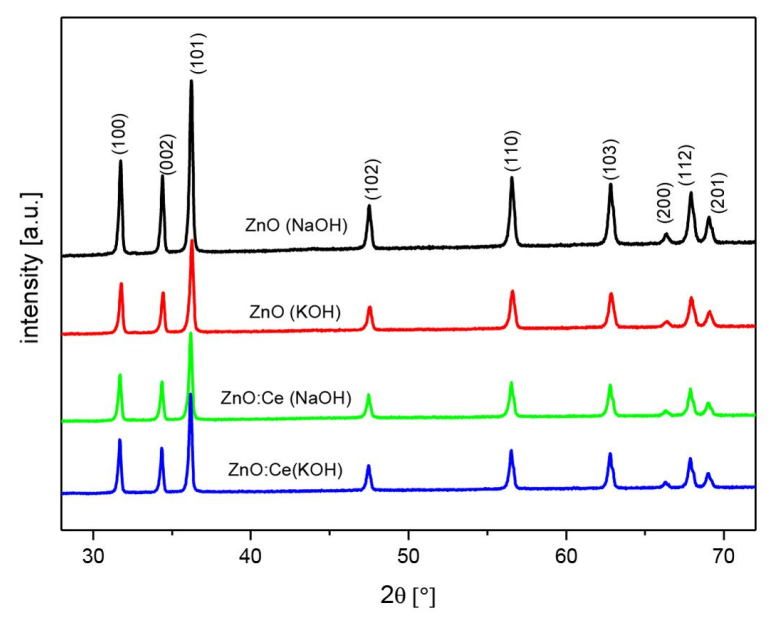

Fig. 3. XRD patterns of pure and Ce-doped $\mathrm{ZnO}$ nanorods synthesized with $\mathrm{NaOH}$ and $\mathrm{KOH}$.

To confirm the chemical composition, the assynthesized pure and $\mathrm{Ce}$-doped $\mathrm{ZnO}$ nanorods were characterized by FT-IR spectroscopy at room temperature. FT-IR spectra of all samples are shown in Fig. 5. Various low intensity signals at $507 \mathrm{~cm}^{-1}, 881 \mathrm{~cm}^{-1}, 1019 \mathrm{~cm}^{-1}, 1436 \mathrm{~cm}^{-1}$, $1627 \mathrm{~cm}^{-1}, 2373 \mathrm{~cm}^{-1}, 2940 \mathrm{~cm}^{-1}$ and $3444 \mathrm{~cm}^{-1}$ are observed in all the spectra. The very strong peak appearing at $507 \mathrm{~cm}^{-1}$ could be attributed to the 
Table 1. Cell parameters a and c, c/a ratio, cell volume V, Zn-O bond length (L) and the degree of crystallinity $\mathrm{X}_{\mathrm{C}}$ of the samples.

\begin{tabular}{ccccccc}
\hline Sample & $\mathrm{a}[\mathrm{nm}]$ & $\mathrm{c}[\mathrm{nm}]$ & $\mathrm{c} / \mathrm{a}$ & $\mathrm{X}_{\mathrm{c}}$ & $\mathrm{V}\left[\AA^{3}\right]$ & $\mathrm{L}[\mathrm{nm}]$ \\
\hline \hline Pure $\mathrm{ZnO}(\mathrm{NaOH})$ & 0.3251 & 0.5208 & 1.6019 & 1.96 & 47.667 & 0.19783 \\
Ce-doped $\mathrm{ZnO}(\mathrm{NaOH})$ & 0.3255 & 0.5214 & 1.6018 & 1.45 & 47.839 & 0.19806 \\
Pure $\mathrm{ZnO}(\mathrm{KOH})$ & 0.3248 & 0.5204 & 1.6022 & 1.26 & 47.543 & 0.19763 \\
Ce-doped $\mathrm{ZnO}(\mathrm{KOH})$ & 0.3256 & 0.5215 & 1.6016 & 2.29 & 47.878 & 0.19806 \\
JCPDS Card No. 79-2205 & 0.3250 & 0.5207 & 1.6020 & $/$ & 47.629 & 0.19776 \\
\hline
\end{tabular}

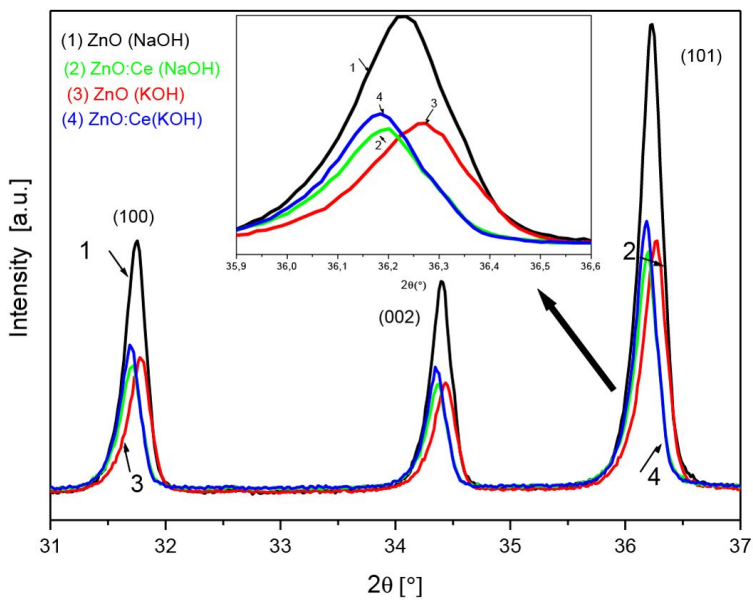

Fig. 4. XRD patterns of the most pronounced peaks of pure and $\mathrm{Ce}$-doped $\mathrm{ZnO}$ nanorods synthesized with $\mathrm{NaOH}$ and $\mathrm{KOH}$ (inset: high magnification of ( $\left.\begin{array}{llll}1 & 0 & 1\end{array}\right)$ peak).

metal oxygen $(\mathrm{Zn}-\mathrm{O})$ bonds, confirming the formation of $\mathrm{ZnO}$. The signal at $3444 \mathrm{~cm}^{-1}$ is due to the stretching mode of the $\mathrm{O}-\mathrm{H}$ group which reveals the existence of a small amount of water absorbed by the $\mathrm{ZnO}$ nanorods. The signal at $1627 \mathrm{~cm}^{-1}$ corresponds to $\mathrm{O}-\mathrm{H}$ bending vibration, while that at $2940 \mathrm{~cm}^{-1}$ shows the $\mathrm{C}-\mathrm{H}$ stretching and that at $2373 \mathrm{~cm}^{-1}$ represents the stretching vibration of $\mathrm{CO}_{2}$ [28]. The very small signal at around $881 \mathrm{~cm}^{-1}$ is caused by $\mathrm{C}-\mathrm{O}$ bond stretching [29]. The small band at $1019 \mathrm{~cm}^{-1}$ indicates the stretching vibration of $(\mathrm{NH})-\mathrm{C}-\mathrm{O}$ group, and that located at $1435 \mathrm{~cm}^{-1}$ is due to aromatic $-\mathrm{CH}$ stretching vibrations [30]. The low intensities of the observed signals confirm that the synthesized nanorods are of high purity. The $\mathrm{Zn}-\mathrm{O}$ vibration band observed in pure $\mathrm{ZnO}$ at $507 \mathrm{~cm}^{-1}$ is shifted to $510 \mathrm{~cm}^{-1}$ in Ce-doped $\mathrm{ZnO}$ nanorods. The decrease in the band intensity and the occurrence of a shoulder around $700 \mathrm{~cm}^{-1}$ in the doped samples spectra is probably due to the presence of cerium ions. It has been reported that the FT-IR spectrum of ceria exhibits strong broad band below $700 \mathrm{~cm}^{-1}$ which is due to $\delta(\mathrm{Ce}-\mathrm{O}-\mathrm{C})$ mode [31]. It should be noted that all vibration bands detected in the FT-IR spectra, related to the carbonic bonds are very low, indicating the presence of very small quantity of $\mathrm{C}$ atoms originated from the atmosphere.

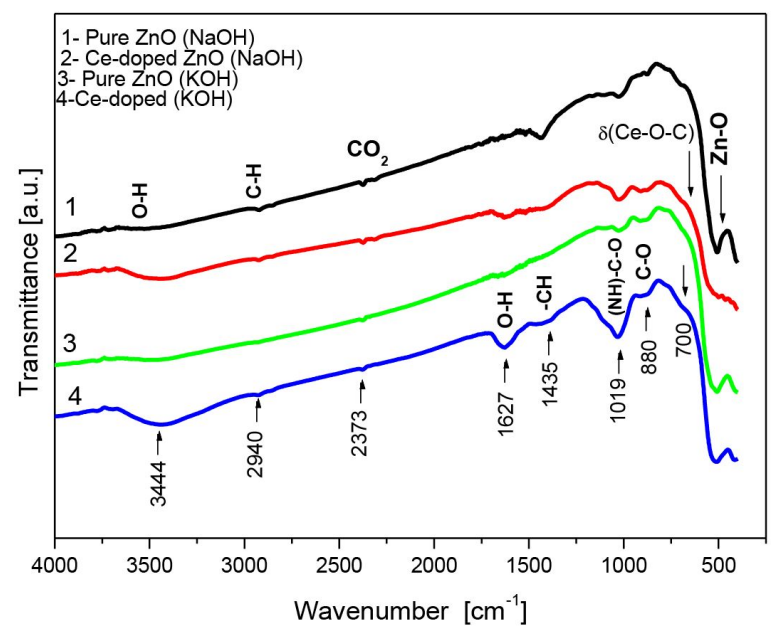

Fig. 5. FT-IR spectra of pure and Ce-doped $\mathrm{ZnO}$ nanorods synthesized with $\mathrm{NaOH}$ and $\mathrm{KOH}$.

The micro-Raman spectroscopy has been used to complete the structural characterization of the prepared samples. The micro-Raman spectra of pure and Ce-doped $\mathrm{ZnO}$ nanorods, synthesized hydrothermally in $\mathrm{NaOH}$ and $\mathrm{KOH}$ caustic bases, are illustrated in Fig. 6. All the spectra were recorded at room temperature using a $785 \mathrm{~nm}$ excitation wavelength. It is well known that $\mathrm{ZnO}$ wurtzite structure 
possesses 12 phonon active modes: three acoustic and nine optical modes [22]. As shown in Fig. 6, in the pure $\mathrm{ZnO}$ spectra, there are two more intense Raman peaks at $419 \mathrm{~cm}^{-1}$ and $438 \mathrm{~cm}^{-1}$ and five low intense peaks at $267 \mathrm{~cm}^{-1}, 335 \mathrm{~cm}^{-1}$, $378 \mathrm{~cm}^{-1}, 405 \mathrm{~cm}^{-1}$ and $534 \mathrm{~cm}^{-1}$. The sharp and strong peak at $438 \mathrm{~cm}^{-1}$ is assigned to $\mathrm{E}_{2}$ (high) mode of the $\mathrm{ZnO}$ wurtzite structure. This vibrational mode indicates high crystallinity of wurtzite $\mathrm{ZnO}$. This mode is typical of $\mathrm{P}_{3} \mathrm{mc}$ symmetry and originates from the oxygen vibration in $\mathrm{ZnO}[19,32]$. The intense peak at $419 \mathrm{~cm}^{-1}$ is assigned to $\mathrm{E}_{1}$ (TO) modes of $\mathrm{ZnO}$ nanorods, which is due to the presence of oxygen vacancies and/or the interstitials zinc or their complexes [33]. This peak was also observed in big $\mathrm{ZnO}$ crystals [34]. This result confirms the EDAX measurements of the synthesized $\mathrm{ZnO}$ nanorods. The low intensity band observed at $331 \mathrm{~cm}^{-1}$ is attributed to the second-order Raman spectrum arising from zone-boundary phonons ( $E_{2}$ (high) $-E_{2}$ (low)) of hexagonal $\mathrm{ZnO}$ [35]. The peak of $\mathrm{ZnO}$ nanorods observed at $534 \mathrm{~cm}^{-1}$, which is related to multiphonon processes, can be assigned to the second order Raman spectrum arising from zone-boundary phonons $\left(E_{2}\right.$ (low) $+E_{2}$ (high)) due to combination of first order modes. This peak was observed in $\mathrm{ZnO}$ nanorod at $542 \mathrm{~cm}^{-1}$ [33]. The observed phonon peak shift in Raman spectra may be attributed to phonon localization by defects such as oxygen deficiency, zinc excess and surface impurities $[33,36]$. The peak located at $378 \mathrm{~cm}^{-1}$ can be assigned to $A_{1}(T O)$ vibration modes of wurtzite $\mathrm{ZnO}$ [37]. The peak around $405 \mathrm{~cm}^{-1}$ is assigned to $A_{1}(\mathrm{TO})$ phonon oxygen-dominated polar mode in which $\mathrm{Zn}$ and $\mathrm{O}$ atoms move parallel to the $\mathrm{c}$ axis in the $\mathrm{ZnO}$ hexagonal structure [38]. The peak at $267 \mathrm{~cm}^{-1}$ is assigned to laser plasma lines [33]. In $\mathrm{Ce}$-doped $\mathrm{ZnO}$ nanorods micro-Raman spectra, an additional less intense peak is observed at around $461 \mathrm{~cm}^{-1}$. This signal originates from the Raman active mode, characteristic of $\mathrm{CeO}_{2}$ fluorite structured materials with $\mathrm{F}_{2 \mathrm{~g}}$ symmetry, and corresponds to the ceria $\mathrm{Ce}-\mathrm{O}_{8}$ vibrational unit $[37,39$, 40].

As can be seen from Fig. 6, the Raman peaks in Ce-doped $\mathrm{ZnO}$ slightly shift to lower

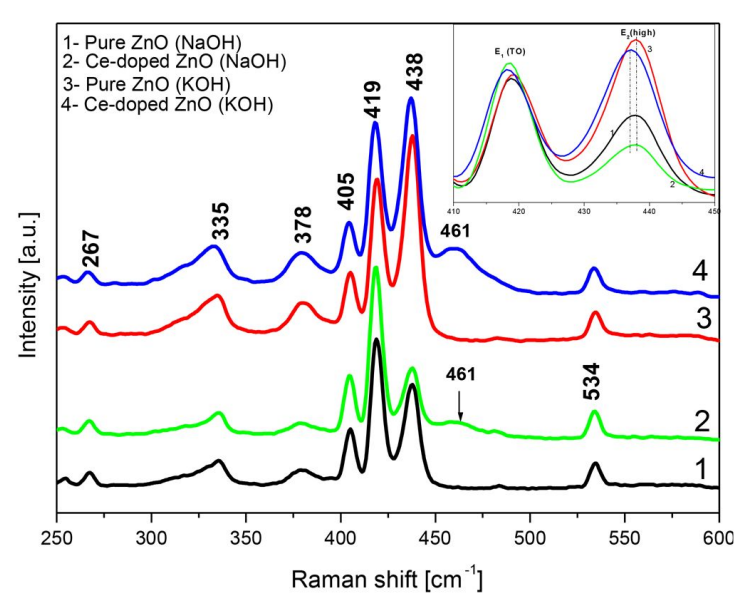

Fig. 6. Micro-Raman shifts of pure and Ce-doped $\mathrm{ZnO}$ nanorods synthesized with $\mathrm{NaOH}$ and $\mathrm{KOH}$ (inset: high magnification of $\mathrm{E}_{1}$ (TO) and $\mathrm{E}_{2}$ (high) modes).

frequencies compared to those of undoped $\mathrm{ZnO}$, suggesting the existence of strain variations in $\mathrm{Ce}$ doped $\mathrm{ZnO}$ nanorods. Generally, the red shift of $\mathrm{E}_{2}$ (high) and $\mathrm{A}_{1}$ (TO) modes towards lower frequencies may be attributed to optical phonon confinement [41]. Thus, we can suggest that $\mathrm{Ce}$ ions favor the amplification of optical phonon confinement when caustic bases are used in the hydrothermal synthesis route. The nanostructures length is much larger than the diameter, which means that the confinement effect mainly occurs along the diameter direction. Apart from Ce-doped $\mathrm{ZnO}(\mathrm{NaOH})$ spectrum, the $419 \mathrm{~cm}^{-1}$ peak intensity $\left(\mathrm{E}_{1}\right.$ (TO) mode of $\mathrm{ZnO}$ nanorods) remains almost unchanged in all the spectra. This indicates that the morphologies of the synthesized materials are all of nanorod type, which is confirmed by the SEM micrographs. The increase in the intensity of this peak in Ce-doped $\mathrm{ZnO}(\mathrm{NaOH})$ indicates the change in the morphology of the prepared nanostructures (inset in Fig. 6) and is confirmed the SEM analysis. In contrast, the intensity of $E_{2}$ (high) mode $\left(438 \mathrm{~cm}^{-1}\right)$ strongly changes. In $\mathrm{ZnO}(\mathrm{KOH})$ the intensity of $\mathrm{E}_{2}$ (high) mode peak is higher than that of $\mathrm{E}_{1}$ (TO) mode, whereas an inverse behavior is observed in $\mathrm{ZnO}(\mathrm{NaOH})$. The peaks related to $\mathrm{E}_{2}$ (high) mode in $\mathrm{ZnO}(\mathrm{KOH})$ are relatively intense compared to those of $\mathrm{ZnO}(\mathrm{NaOH})$. This may be explained by 
the differences in crystalline quality of the different nanorods. It can also be seen that the $E_{2}$ (high) modes are not only shifted, but also broadened and have an asymmetric line shape. Samuel et al. [33] calculated the broadening and the shift of the Raman peaks of $\mathrm{ZnO}$ nanotrods and nanotubes based on the confinement model. This study clearly showed that the shift, broadening and asymmetric broadening of Raman peaks were caused by the anharmonic effects originating from quantum phonon effect confinement.

\section{Conclusion}

In this paper, successful synthesis of undoped and $\mathrm{Ce}$-doped $\mathrm{ZnO}$ nanorods with different solutes $\mathrm{NaOH}$ and $\mathrm{KOH}$ by simple hydrothermal method was reported. Structural and morphological properties of the samples were investigated. All synthesized materials have nanorods morphology with $1.5 \mu \mathrm{m}$ to $2 \mu \mathrm{m}$ in length and $250 \mathrm{~nm}$ to $300 \mathrm{~nm}$ in diameter. Ce-doped $\mathrm{ZnO}(\mathrm{NaOH})$ nanorods gather to form a flower-like nanostructures with uniform distribution. EDAX measurements show that the rods are $\mathrm{Zn}$ rich with high concentration of oxygen vacancies. XRD analysis put into evidence the hexagonal wurtzite phase with very good crystallinity of prepared samples. The introduction of cerium ions into $\mathrm{ZnO}$ lattice deteriorates the crystalline quality of $\mathrm{ZnO}(\mathrm{NaOH})$ and improves that of $\mathrm{ZnO}(\mathrm{KOH})$. The insignificant intensities observed in FT-IR signals confirm that the synthesized nanorods are of high purity. The microRaman measurements show that the peaks related to $\mathrm{E}_{2}$ (high) mode in $\mathrm{ZnO}(\mathrm{KOH})$ are relatively intense compared to those of $\mathrm{ZnO}(\mathrm{NaOH})$. Raman peaks of Ce-doped $\mathrm{ZnO}$ nanorods shift towards low frequencies after the introduction of $\mathrm{Ce}$ ions into $\mathrm{ZnO}$ lattice. The Raman spectroscopy studies clearly show a shift, broadening and asymmetric broadening of Raman vibrational modes due to the anharmonic effects originating from quantum phonon effect confinement.

\section{References}

[1] Norton D.P., Heo Y.W., IVill M.P., Pearton S.J., Chosholm M.F., Steiner T., Mater. Today, 7 (2004), 34.
[2] SaAd L., Mary R., J. Serb.-Chem. Soc., 73 (2008), 997.

[3] Nirmala Jothi N.S., Gunaseelan R., SagayaraJ P., Arch. Appl. Sci. Res., 4 (2012), 1698.

[4] Sun Z.P., LiU L., Zhang L., Jia D.Z., Nanotechnology, 17 (2006), 2266.

[5] Wahyuono R.A., Schmidt C., Dellith A., DelLith J., Schulz M., Seyring M., Rettenmayr M., Plentz J., DietzeK B., Open Chem., 14 (2016), 158.

[6] El-Sayed A.M., Yakout S.M., J. Res. Nanotechnology, 1 (2016), 690025.

[7] LiU X., Wu X., CaO H., Chang R.P.H., J. Appl. Phys., 95 (2004), 3141.

[8] Mishra B.G., Rao G.R., Bull. Mater. Sci., 25 (2002), 155.

[9] Yang B., Kumar A., Zhang H., Feng P., KatiYAR R.S., Wang Z., J. Phys. D. Appl. Phys., 42 (2009), 045415.

[10] Zhang H., Feng J., Wang J., Zhang M., Mater. Lett., 61 (2007), 5202.

[11] Sahu D., Panda N.R., Acharya B.S., Panda A.K., Ceram. Int., 40 B (2014), 11041.

[12] Bhosle V., Tiwari A., Narayan J.J., Appl. Phys., 100 (2006), 033713.

[13] DAR G.N., UMAR A., Zaidi S.A., Ibrahim A.A., Abaker M., Baskoutas S., Al-Assiri M.S., Sens. Actuator. B, 173 (2012), 72.

[14] Ni Y.H., Wei X.W., Hong J.M., Ye Y., Mater. Sci. Eng. B, 121 (2005), 42.

[15] Xia C., Hu C., Zhou P., J. Exp. Nanosci., 8 (2013), 69.

[16] Aisah N., Gustiono D., Fauzia V., Sugihartono I., Nuryadi R., IOP Conf. Ser. Mater. Sci. Eng., 172 (2017), 012037.

[17] Chelouche A., Touam T., Duouadi D., Aksas A., Optik, 125 (2014), 5626.

[18] Li G.R., LU X.H., Zhao W.X., Su C.Y., Tong Y.X., Cryst. Growth Des., 8 (2008), 1276.

[19] Meddouri M., Hammiche L., Slimi O., DJouadi D., Chelouche A., Mater. Sci.-Poland, 34 (2016), 659.

[20] Rodnyi P.A., Khodyuk V., Opt. Spectrosc., 111 (2011), 776.

[21] Kohan A.F., Ceder G., Morgan D., Van De WALle C.G., Phys. Rev. B, 61 (2000), 15019.

[22] Xu C., Xu G., Liu Y., Wang G., Solid State Commun., 122 (2002), 175.

[23] Zhang H.Z., Kong Y.C., Wang Y.Z., Du X., BaI Z.G., WANG J.J., YU D.P., Ding Y., Hang Q.L., FEng S.Q., Solid State Commun., 109 (1999), 677.

[24] Danishvar N., Aber S., Seyed Dorraji M.S., Khataee A.R., Rasoulifard M.H., Sep. Purif. Technol., 58 (2007), 91.

[25] Alias S.S., Ismail A.B., Mohamad A.A., J. Alloys Compd., 499 (2010), 231.

[26] Zhao X., Li M., Lou X., Adv. Powder Technol., 25 (2014), 372. 
[27] Rem F., Xin R., Ge X., Leng Y., Acta Biomater., 5 (2009), 3141.

[28] Geetha A., Mallika J., A. J. Sci. Technol., 3 (2015), 72.

[29] Dandeneau C.S., JeOn Y.H., Shelton C.T., Plant T.K., Cann D.P., Gibbons B.J., Thin Solid Films, 517 (2009), 4448.

[30] Awwad A.M., Albiss B., Ahmad A.L., Adv. Mat. Lett., 5 (2014), 520.

[31] Dos Santos M.L., Lima R.C., Riccardi C.S., Tranquilin R.L., Bueno P.R., VAREla J.A., Longo E., Mater. Lett., 62 (2008), 4509.

[32] Alim K.A., Fonoberov V.A., Shamsa M., BaLADIN A.A., J. Appl. Phys., 97 (2005), 124313.

[33] Samuel S.M., Koshy J., Chandran A., George K.C., Indian J. Pure Appl. Phys., 48 (2010), 703.

[34] Ristic M., Music S., Ivanda M., Popovic S., J. Alloys Compd., 397 (2005), L1.

[35] Reddy A.J., Kokila M.K., Nagabhushana H., RaO J.L., Shivacumara C., Nagabhushana B.M., ChaKRadHAR R.P.S., Spectrochim. Acta A, 81 (2011), 59.
[36] Samanta K., Bhattacharya P., Katiyar R.S., Iwamoto W., Pagliuso P.G., Rettor C., Phys. Rev. B, 73 (2006), 245213.

[37] Chouchene B., Ben ChaAbane T., Balan L., Girot E., Mozet K., Medjahdi G., Schneider R., Beilstein J. Nanotechnol., 7 (2016), 1338.

[38] Sreenivas K., Kumar S., Choudhary J., Gupta V., Pranama J. Phys., 65 (2005), 809.

[39] Francisco M.S.P., Mastelaro V.R., Nascente P.A.P., Florentino A.O., J. Phys. Chem. B, 105 (2001), 10515

[40] Xu Q.H., Xu D.M., GuAN M.Y., Guo Y., QI Q., LI G.D., Sens. Actuator. B, 177 (2013), 1134.

[41] Richter H., Wang Z.P., Ley L., Solid State Commun., 39 (1981), 625.

Received 2017-04-20

Accepted 2019-04-23 